\title{
The educational phenomenon between ideology and utopia. Paul Ricoeur's thought: foundations for an emancipatory education
}

\author{
Manoel Tavares*
}

\begin{abstract}
Paul Ricoeur's thoughts have not yet been discussed in Brazil, except in purely academic circles. The present article has a prime objective of opening up for debate the useful fundamental aspects of Paul Ricoeur's thoughts - the issues related to ideology and utopia, its differences and its analogies -, and to demonstrate that such themes, in the way that they typify social and cultural imagination of a specific population, they can provide important basis for new analysis, thoughts and guidelines of the educational system and of education. This is always configured through symbolic representations of ideological or utopian nature, survives in the conflict, which is not always pacific, between one and the other pending, sometimes, towards, a somewhat restrictive, ideology and other times towards utopia, a transgressor within the existing order. Formation towards true citizenship and towards emancipation demands an assumption of new presupposed theories, whether within a sociological and axiological level or within an epistemological level, presupposed that, unable to disconnect from the ideological contexts, assuming new outlooks which can reconstruct universes of innovative meanings within the educational context.
\end{abstract}

Keywords: Ricoeur. Ideology. Utopia. Education. Emancipation. Metaphoric representation.

\section{O fenômeno educativo entre ideologia e utopia. $O$ pensamento de Paul Ricoeur: Base para uma educação emancipatória}

\footnotetext{
* Doutor em Filosofia pela Universidade de Sevilha (Spain), Universidade de Coimbra, PT e Universidade Federal do Rio de Janeiro (UFRJ). Professor do Programa de Pós-Graduação em Educação na Universidade Nove de Julho (UNINOVE).E-mail: manuel.tavares@outlook.com.br
} 
Resumo: O pensamento de Paul Ricoeur não é, ainda, muito discutido no Brasil, salvo em meios estritamente acadêmicos. O presente artigo tem por finalidade pôr à discussão um dos aspectos fundamentais do profícuo pensamento de Paul Ricoeur - as questões relacionadas com a ideologia e utopia, suas diferenças e analogias -, e demonstrar que tais temáticas, na medida em que tipificam a imaginação social e cultural de um determinado povo, podem constituir bases importantes para novas análises, reflexões e linhas de orientação do sistema educativo e da educação. Esta é, sempre, configurada por representações simbólicas de natureza ideológica ou utópica, sobrevive no conflito, nem sempre pacífico, entre uma e outra pendendo, umas vezes para a ideologia, algo aprisionadora, outras para a utopia, transgressora da ordem existente. A formação para uma cidadania plena e para a emancipação exige a assunção de novos pressupostos teóricos, quer a nível sociológico e axiológico quer a nível epistemológico, pressupostos que, não podendo desligar-se de contextos ideológicos, supõem, todavia, novos olhares que possam reconstruir universos de sentido inovadores no âmbito educativo.

Palavras-chave: Ricoeur. Ideologia. Utopia. Educação. Emancipação. Representações metafóricas.

\section{El fenómeno educativo entre ideología y utopía. El pensamiento de Paul Ricoeur: Bases para una educación emancipadora}

Resumén: El pensamiento de Paul Ricoeur no es aún muy discutido en Brasil, excepto en la academia. En este artículo se pretende discutir los aspectos fundamentales del pensamiento fecundo de Paul Ricoeur - las cuestiones relacionadas con la ideología y utopía, sus diferencias y similitudes - y demostrar que estos problemas, en la medida en que tipifican la imaginación social y cultural de un pueblo en particular pueden ser importantes bases para un posterior análisis, reflexiones y orientaciones del sistema educativo y de la educación. La educación es siempre configurada por representaciones simbólicas de naturaleza ideológica o utópica, sobrevive en el conflicto, no siempre pacífico, entre una y otra. Unas veces la tendencia es para una educación ideológica, algo encarcelada, otras hacia la utopía, transgresiva del orden existente. La formación hacia la plena ciudadanía y emancipación requiere la asunción de nuevos supuestos teóricos, tanto al nivel sociológico y axiológico cuanto al nivel epistemológico, supuestos que no pueden separarse de los contextos ideológicos, pero que suponen, sin embargo, nuevas miradas que puedan reconstruir universos de sentido innovadores en el campo educativo. 
Palabras clave: Ricoeur. Ideología. Utopía. Educación. Emancipación. Representaciones metafóricas.

\section{I.}

The educational question does not represent a nuclear theme in Paul Ricoeur's thoughts. Beyond thoughts and considerations regarding university teaching, in regards to the academic crisis of ' 68 and regarding his experience as the Headmaster of the University of Nanterre, there is no systematic thought regarding instruction and education. However, his anthropological and ethical ideas, such as the philosophical principals to which they imply, having as an objective the construction of an ontology, which will be in continuous construction, can contribute to build profound thoughts in an educational context and to develop educational theories.

For this reason, the questions regarding ideology and utopia, in their analogical and deferential relations considered as configured concepts of social actions, can constitute indispensable fundamental theories for a better understanding of the relations between power and counter-power, the resistance to change and the change that vertically and horizontally crosses the educational system as well as the phenomenons in the educational system in Portugal. In a society, characterized as being somewhat solipsistic and void of axiology and of political representations, school, as a place of dialogic communication, can and should be a privileged place for a projective and liberating type of education in relation to all ancient traditions and imprisoning ideologies.

Effectively, the ideological system of a specific society, while a symbolic place of expression, in its different levels of production, invention and diffusion, represents a privileged context of confrontation, conflict, mediation and conciliation in the bosom of which the social actors enunciate their desires, dreams, projects and aspirations keeping in mind social transformation. In reality, the system of ideological 
representation is never a true translation of social relationships but is, frequently, a deformation in the social relationships existent in the sense of legitimacy and the preservation of a specific social order.

In this way, the ideology is conservative in the degree that it opposes everything that can pose a threat to the established order. Still, it is not correct to identify all ideology as a system of mysticism given that it, while a symbolic representation, it has a positive function in social action. In final analysis, the ideology is, in it's multiple functions, an interpretation of social living and cannot be thought of unless it is thought of as a constant dialectic tension with a utopic idea, bearing in mind that both constitute expressions of social imagination.

In contrast, Utopia - bearing in mind it's positive dimension - is innovating when it ultimately has a creation of a system of representation that is not in conformity with the established system. In any case, utopia is a symbolic representation applicable to another place and time and not to a present place and time. It is for that reason that P. Ricoeur speaks of "ucronia", when referring to the time of the utopic project while time is refigured through narrative fiction. ${ }^{1}$

Assuming that the educational phenomenon cannot subsist without the ideological principals that, throughout time, have been contributing to its structuring and to the cohesion of all the intervenients in the educational system, it is our conviction that it has been living, systematically, in an insufferable conflict among ideology, something imprisoning, and utopia that tends to transgress the complex game of the existent relationships. There is no education without solid principles that base it, or without any guiding objectives, or so little without a normative system to which everyone should submit. And, in this aspect, of the formal point of view, there is no distinction between the thoughts of the right-wing value systems and those of the left-wing value systems. The consciousness of who we are, of our collective identity, of what we want and where we

1 Cf. Ricoeur, P. TA, p. 427. See also, Temps et récit, 3. Le temps raconté, p. 11-12. 
are going is, unavoidably, tied up to ideological principles that, most of the time, the intervening social actors are unaware of in the educational process. Though, this consciousness, configured by an ideology is, frequently, the generator of mechanisms that simply allow the system to function, reproducing and perpetuating the existent social relationships. To prepare the youth for what exists, for a political, social and pre-defined economic reality has been one of the ideological functions of teaching. On the other hand, almost silently, dynamics of transformation emerge that represent an aggression towards the present, a critical separation in relation to what is acceptable as unquestionable and inalterable. This horizontal tendency - because it doesn't come from above - that passes by the educational system, in the sense of its deconstruction/reconstruction and reconfiguration of links to utopia.

Nowadays, the educational system and the effective education exist in a not very dialectic tension between two orientations or different and antagonizing mandates and: on one hand, the demands in educating/training for excellence, bearing in mind the demands for efficacy demanded by the techno-scientific society of neo-liberal savage capitalism and, on the other, the demand for a deep democratization that assumes a different organic from the educational system and new relationship rules in the context of the educational community. The first demand is governed by ideological principles related to the presupposition that the only model for society and its regime is capitalism and, at the same time, the only school paradigm that corresponds to it is that that existed before the massification of teaching. Only that one, elitist in its essence and in its purposes, corresponds to the competitive economy of market. We will call it the educational regulative model, glossing the terminology of Boaventura de Sousa Santos, applied to sociology (SANTOS, 2000, p. 29-31).

The second, somewhat timid, democratic in its principles and purposes, tries to be integral and multicultural, tolerant in relation to the differences that exist in the educational system today and, on the other hand, seeking, in the axiological, epistemological and pedagogical point 
of view to give answer to its diversity. We will call it the educational emancipation model, along the same lines as B.Sousa Santos and of other thinkers, such as Habermas and P. Ricoeur himself.

Now, it is in the context of this conflict, not very dialectic as was said, that the subject of the ideology and of the utopia has pertinence in the domain of the educational system and of education.

The ideology is, on one hand, reproductive and perpetuating of the system of relationships and existent social correlations and, on the other, a factor of social cohesion; utopia, on its own, is an aggression-transgression to and of the present, a critical separation that has as a purpose to seek its transformation, but can also be, in its fragility, a pathological discourse producing of totalitarian systems. In this sense, the ideology and the utopia can emerge as opposite distortions but, at a deeper level, they have complementary constituent functions.

Ideology and utopia are, in this way, elements that contribute for the constitution of the present analogical liaisons in society and in history, but they also possess their own pathology that ends up obscuring such function. Therefore, it is necessary to critic the ideology and of the utopia and such a critic is taken into effect by the practical reason, for a reason that is not dissociated from the existent social reality.

From K. Mannheim's concept of incongruity, the construction of the integral and configured function of the ideology and of the subversive and reconfigured function of the utopia is possible. Mannheim tried to place the problems of ideology and utopia into a common framework, that is, considering them as attitudes of deviation in relation to the reality.

In his work Ideology and utopia, Ricoeur affirms that it is necessary to seek the functions of ideology and of utopia in the literary and semantic expressions to, later on, establish the correlation between them. It is, therefore, from the concept of incongruity of K. Mannheim that its investigation is developed: 
I take this concept as a starting point because the possibility of incongruity, of discrepancy, already presupposes in a lot of ways that the individuals, just as the collective entities relate to their own lives and with the social reality, not just in agreement with the way of a participation without any distance, but precisely according to the way of incongruity. All the figures of incongruity should be part of our possession to society. I believe that this is certain to the point that social imagination is part constituent of the social reality. Here the supposition consists precisely in that a social imagination, a cultural imagination operates in a constructive and destructive way as a statement and as a refusal of the present situation. Therefore, it could be a fruitful hypothesis that the polarity between the ideology and the utopia has to do with the different figures of the typical incongruity of the social imagination. It is perhaps the positive aspect of one and the positive aspect of the other are in the same complementary relationship in that the negative and pathological aspect of one with the negative and pathological aspect of the other (RICOEUR, 1989, p. 46-47).

The previous text is sufficiently clarifying in relation to the problem of ideology and of utopia in its several aspects - positive and negative and, moreover, in relation to the existent polarity among both.

The thoughts on ideology and utopia, in the positioning of Ricoeur, should be included in the plan of the emphasis that it attributes to the character placement of the human existence and in the context of the practical reason, always bearing in mind, on one hand, the "critical recapitulation" 2 of the inheritances of the philosophical tradition and, on the other, the projects of a society in that the individuals are freer in the bosom of "fair institutions". ${ }^{3}$ It is in this aspect that, with some pertinence, the formation of new generations is placed. To form for the assumption of a full citizenship is to assume other theoretical presuppositions, either from the sociological

\footnotetext{
2 An expression frequently used by Ricoeur in the domain of his own political and ethical ideas. Cf (1993). Amor y justicia. Madrid : Caparrós Editores.

3 An expression frequently used by Ricoeur in the domain of his own political and ethical ideas. Cf (1993). Amor y justicia. Madrid : Caparrós Editores.
} 
and axiological or epistemological point of view. Ricoeur's reflections on ideology and utopia establish some ruptures, bearing in mind the traditional conceptions to the theme in analysis that, in synthesis, were mentioned previously. It can be said that, although its reflections are conceptual, its starting point concerning the reflection on ideology is Max Weber's concept of social action and of social relationship. According to this author, «there is social action starting from the moment in that the human behaviour is significant for the individual agents and in that the behaviour of one of them is guided in function of the behaviour of the other». ${ }^{4}$ The concept of social relationship is linked to the significance of the action, to the ideas of stability and predictability of a system of meaning.

That which, in fact, interests Ricoeur is the conceptual network of the human action, bearing in mind the elaboration of a philosophical anthropology that is the widest and possibly holistic. Separating the postmodern conceptions of neo-liberalism and of the globalization theorists that declare the end of ideology and of utopia, as well as the end of history, Ricoeur reserves in his reflexive course a privileged place to the thematic of the ideology and of the utopia and to the relationships between them.

In the work already referred to, the author defends the thesis that the relationship among both typifies what he designates as social and cultural imagination. Ideology is the portrayed imagination, in that it repeats and justifies what exists through an image of what is real; utopia, in its on way, has the capacity to provide a new outlook on life, it has, therefore, a fictional power. It can be affirmed, then, that if ideology is a portrayed imagination, utopia is a fictional imagination, «it is always a glance from a place that doesn't exist» (RICOEUR, 1989, p. 285).

Both the ideological speech and the utopian narratives usually articulate with the thematics of metaphor and imagination. It can be said that

4 Ricoeur, P. Science et idéologie. TA, p. 339 
these last ones constitute the central context of the lessons on ideology and utopia. The metaphor - Ricoeur adds - «is the rhetorical process by which the speech frees the power that has certain fictions to re-describe what the reality actually is». In another moment, the metaphor is presented «as a discourse strategy that, when preserving and developing the creative power of the language, it preserves and develops the heuristic power developed by fiction » (RICOEUR, 1980, p. 15-14).

It is usually affirmed that the order of metaphoric speech is different from the literal order in that the first constitutes a deviation of the literal meaning. Now, Ricoeur sustains that the metaphor cannot be considered as a deviation in relation to literal speech, but that it should be understood as the result of a semantic interaction, of a tension between the word and the sentence in which the metaphor appears. The literal meaning is the lexical, with no existing primordial relationship between a word and its representation. The metaphor is, therefore, one of the possible representations of the word. The meaning of a word is, above all, the use it has and, therefore, it is not definitively something established. The metaphor is an event of the speech of which its purpose is to reconstruct a universe of an innovative sense that can re-create the order of the world and of existence. In the same way that in every creative act therein exists a moment of transgression and a moment where meaning is transposed, utopia while a metaphor is a transgression of a semantic order - it can, inclusively, be of an existent educational or social order - and a transposition of meaning seeing as how it has a symbolic power of re-describing reality.

In the same way that is not correct to describe the metaphoric representation as a deviation related to the literal meaning, it is also not the description of the ideological representation as a deviation of the scientific representation. Ricoeur attributes great importance to the metaphoric meaning and the ideological meaning, seeing as how it considers that the true meaning is, also, in the metaphorical and ideological context, along 
the same line as Aristotle's "plurality of the levels of scientificity". ${ }^{5}$ In this perspective, the metaphor assumes an ontological pretension because it can be a vehicle for another universe of meaning, that is, for a vision in another way of being, of "to be" (RICOEUR, 1985, p. 281).

In the same way that a metaphor characterizes the meaning of language, ideology is also a symbolic mediation that confers a meaning to human action and social reality. Ricoeur writes:

Ideology is an insuperable phenomenon of social existence, in that social reality has always had a symbolic constitution and it implies an interpretation, in images and representations, of social relationships themselves. ${ }^{6}$

Considering this point of view, the ideological phenomenon appears in all its extension at the level of its significant character; this means that ideology is considered as a system of symbolic significances by which its purpose is the integration of the individuals in a community. Ideology maintains and reinforces a certain social situation and, in this sense, «presents itself with a sign of suspicion» (CRAGNOLINI, 1992, p. 193).

Ricoeur questions the Marxist perspective on ideology, since Marx considers it as just a form of mystification and of falsification of what's real, so that ideology is limited to being understood as a form of alienation. $^{7}$ The Marxist concept of ideology is the denial of autonomy that is conceded to the representations of consciousness. From the conception of ideology as a distortion, Ricoeur initiates a type of "genetic pheno-

$5 \quad$ Ricoeur, P. Science et idéologie. TA, p. 335

6 Ricoeur's intention is not to refute Marxism, but to «once again situate and strengthen some of his declarations regarding the "deformative" function» of ideology. IU, p. 211.

7 Ricoeur's intention is not to refute Marxism, but to «once again situate and strengthen some of his declarations regarding the "deformative" function» of ideology. IU, p. 211. 
menology" (1989, p. 326), that is, a regressive analysis of meaning, «an attempt to go deeper seeking under the surface of the meaning apparent the most fundamental meanings» $(1989$, p. 326), the deepest meanings. The Marxist concept of ideology as distortion defines it, according to Ricoeur, to a superficial and reductive level. In the Marxist sense, reality is a productive activity, the praxis and, before it, ideology is a mystification of that reality, that is to say, it is a false consciousness. Ricoeur disagrees with this perspective, as well as those of the philosophers that make the distinction between ideology and science, as is the case of Althusser.

In fact, the contemporary position on the scientific construction is very different from that which existed in the beginning of the 20th century, under the influence of the positivist paradigm. If we take into consideration the epistemological perspective of K. Popper and of the authors of the School of Frankfurt, science is not constructed autonomously in relation to ideology, since the epistemic subject can never be distanced from the pre-comprehensive historic-cultural conditions of reality. The subject is, firstly, a social being, a carrier of values and beliefs, of interests, of perspectives and expectations related to the present and the future. All the subjective and ideological conditions are determiners of the scientific objectivity and the scission between ideology and science. Therein the importance that assumes the criticism in the whole process of scientific construction.

The exposure of the question of ideology and utopia leads Ricoeur to a double discussion: the first, in disagreement with the theses of Althusser, the second, allows the approach to Gadamer and Habermas. Utopia adopts the form of an interest for emancipation and for the precomprehension of tradition. The thoughts on ideology and utopia are the occasion to clarify, in a first approach, the relationship between the doxa and the episteme and, later on, not only the relationships between convention and argument but also between conviction and deliberation. In fact, the action is summed up in the speeches, in the cultural works that, in their own way, are the conditions for a hermeneutics of the subject. As 
Ricoeur says, cogitate is not pure and the praxis is also not immediate. Real life is represented in the speeches that, in their own way, suppose specific convictions that are somewhat strong, somewhat intense or imaginary. These convictions substantialise in ideology and in utopia. The context of ideological or utopian convictions can be exemplified with Marx's thought. The course of Marx's first works, as Ricoeur observes, is a progression in the sense of characterizing what is the "real". The determination of the nature of reality affects the concept of ideology, in that Marx defines as what is not real, as false consciousness and, in a final analysis, as a mystification of reality. The contrast is placed between ideology and reality and not, as will occur later on - for example in Althusser -, between ideology and science.

According to Ricoeur, the representations that allow the social relationship cannot deceive the ideological phenomenon. Unlike Althusser, for whom an epistemological rupture between the ideological representations existed, on the one hand - alienating, in its perspective - and a science of the praxis, on the other hand, the hermeneutic perspective does not establish a rupture between the scientific and the ideological and, besides that, it questions the idea of the non ideological character of the science, above all in the context of the social sciences, since the existence of an axiological neutrality from the scientists is extremely difficult. The whole scientific theory is implied in the concrete socio-cultural conditions and cannot be subtracted from the ideological conditions, that is, to the social, economical, historical and axiological representations. In fact, the scientific theories cannot separate the material and intellectual conditions of a specific social totality:

the social theory cannot be totally separated from the ideological condition; it cannot even accomplish a total reflection nor accede to the point of view capable of expressing the reality that would subtract it to the ideological mediation that the other members of the social group are submitted to (RICOEUR, 1986, p. 358). 
It is not possible that science separates itself from ideology completely, not even is it possible to have a speech on ideology that is not ideological, since the images that a specific social group transmits of itself are interpretations that belong to that same constitution of social relationships.

As a matter of fact, social existence possesses a symbolic structure that is based on language and, therefore, can always be an object of deformation or falsification. The language of real life is the speech of action and only taken into account this symbolic structure can one understand, not only the ideological phenomenon while discourse, but also the understanding of the global sense of ideology itself. What Ricoeur intends is not to deny the legitimacy of the Marxist concept of ideology, but to proceed to its amplification. Along with Habermas, he also thinks that it is necessary to proceed with a criticism of the ideologies with the purpose of emancipation. In any case, if this criticism is not accomplished through hermeneutics - Ricoeur thinks - it can remain in the ideological or utopian context.

Given that social action is symbolically mediated, ideology cannot be avoided; it is a part, in an unquestionable way, of the game of social relationships, in spite of its polemic character; the critical effort intends to elevate ideology to its non-mystifying and integrative level; ideology cannot be considered as just a group of false representations, that is to say, as an illusion that it is opposed to the true representations, but as something that contributes to social cohesion. In fact, one cannot forget that ideology has, in the social and historical point of view, a clear integrative character. Social cohesion cannot be assured without the ideas and other representations that are part of a specific culture. Effectively, they are the habits and customs of a people, the social representations, different levels of language, the beliefs and expectations of a people that confer collective identity to a specific community and, simultaneously, contribute to unity, identity and social cohesion. Besides that, real life is socially significant, it is symbolic; which me- 
ans that ideology, while a symbolic representation, is an omnipresent phenomenon in all social activity.

From this perspective, ideology cannot be exclusively considered as a false representation of reality; nor as an option between what is true and what is false, but it should be seen in the terms of a deliberation about the relationship among what it is a representation and praxis. In fact, ideology is, above all, a representation of reality and distortion is one of the levels inside that representation and not, as Marx intended, the paradigm of the whole ideology. Inclusively, it can be said that in Ricoeur's perspective, ideology should be considered as a symbolic consciousness configured of what's real, in contrast to the configured or transfigured consciousness of the possible that characterizes utopia.

When evoking the debate between Gadamer and Habermas, Ricoeur initiates a development of ideas of hermeneutic character subordinate to the conditions of the whole understanding of historical character. Just like Habermas, Ricoeur assumes that a criticism of the ideologies is possible and that such criticism is sustained by an interest in emancipation. However, this interest always works as an ideology or a utopia and it doesn't keep away from other interests that Habermas describes as interests for instrumental domain and for historical communication supported in the understanding of the cultural inheritances. The task of a critical philosophy is, precisely, the one of exposing the underlying interests to the knowledge (RICOEUR, 1986, p. 390). In fact, society's knowledge doesn't identify with the knowledge of nature, since it always inscribes to a relationship of belonging to a previous cultural tradition. The knowledge of the criticism of the ideologies is condemned to be a partial and fragmentary knowledge, insular. Its incompleteness is founded hermeneutically in the original and insuperable condition that makes separation always a moment of belonging. This way, the criticism of ideologies is something that is never complete.

All man belongs to a history, to a class, to a nation and a culture. It is the integrative character of ideology that has the double function of 
justification and falsification. It is indispensable for a historical community, in that it translates the plurality of addressing issues, the diversity of opinions, the beliefs and the heterogeneity of traditions; however, this integrative function can become alienating if ideology becomes autonomous in relation to social action and to work as a system of representations to which it should submit to the individuals in social practice, allowing it to be, in this case, considered as mystifying and as a false consciousness of reality, in the sense attributed to it by Marx.

Taking into account that ideology is indispensable for any society, Ricoeur considers, in first place, that it is the way a specific social community establishes its cohesion and, in this sense, it is more justifying than mystifying. The systems of legitimacy can be considered ideologies although, as has been observed, all ideology should not be identified with that which Marx calls mystification. In fact, ideology has a more primitive and more fundamental function than all distortion and, in this perspective, constitutes a type of meta-language for the imminent symbolic mediations to the collective social action. As a representation of a culture, it "preserves and conserves the social group just as it is" (RICOEUR, 1989, p. 388).

Furthermore, ideology should also be understood as an integrative representation, a systematic and mystifying distortion. In the first sense, Ricoeur affirms:

these systems of legitimacy can call themselves, if desired, ideologies, with the condition of not identifying ideology and mystification immediately and of recognizing in ideologies a more primitive and more fundamental function than all the distortion, consisting of disposing of a type of meta-language for the imminent symbolic mediations to the collective action. Ideologies are in the first place a type of representation that multiply and reinforce the symbolic mediations, conferring them, for example, the category of narratives, chronicles, by means of which the community somehow 'repeats' its own origin and commemorates it (RICOEUR, 1989, p. 424). 
This function of integration of the ideological phenomenon consists, therefore, in the re-modernisation of the events that a specific community considers constituent of the foundation of its own identity. It is, Ricoeur adds, "of a symbolic structure of social memory». Due to that, in all cultures we find a ritualised commemoration of events that have marked and reaffirmed a specific nation, as is the case of the Independence of United States, the French Revolution, the Revolution of October or, in Portugal's case, the fall of the dictatorship on April 25, 1974. It is the commemoration that allows the encounter of a people with its own origins, that is, with the foundation of a people that is historically recognized. In this particular case, the function of ideology is the one of diffusing the conviction that the founding events are an integral part of the social memory and, through it, of a community's own identity, that is to say, the deep consciousness of belonging to a nation, to a people, to a culture. The image of stability and durability expresses the deepest level of the ideological phenomenon (RICOEUR, 1989, p. 425), since it appeals to a certain sacralisation of the origins, to a sacrality that is part of the mythological history of people.

In this point of view, ideology becomes a dogmatic faith and, frequently, solitary, as we will later on have the opportunity to see. Effectively, ideology is of an insuperable ambiguity, as is shown by Ricoeur ${ }^{8}$ since, on one hand, it serves as a foundation for social communication as it is a type of stock of ideas and of representations that defines the belonging of a people to a culture and, on the other hand, can be dissimulation of a specific oppressive social reality. It is in this double meaning and in this ambiguity that ideology is indissociable from utopia, as we will see. In its negative meaning, ideology can also manifest itself in language. In Habermas' perspective, the phenomenon of dominance is produced in the sphere of communicative action. In fact, Habermas considers that ideology is a distorted way of communication; it is the

8 See Science et idéologie. TA, p. 335-366 
systematic distortion of the dialogical relationships. Therefore there is a need for a criticism that reveals the mystifying an falsifying character of the ideological debate. ${ }^{9}$

Language, above all in its rhetorical expression, is dominance; and all dominance wants to be justified through the most varied instruments that it has at its disposal. Rhetorical language, when appealing to notions that are allegedly universal, has an illusory character, dissimulated; it is a distortion of reality and, therefore, the importance of a hermeneutical criticism of language as a rhetorical and methodological instrument takes into account a criticism of ideology (RICOEUR, 1986, p. 421), a criticism that, as has been said, is never complete.

As a matter of fact, rhetoric is, as history demonstrates, an instrument of legitimacy of power through persuasion. This phenomenon of legitimacy constitutes the second level of the ideological phenomenon (RICOEUR, 1986, p. 423).

However, the function of integration and the function of legitimacy are not independent from one another; on the contrary, the function of integration is prolonged from the one of legitimacy and this in the func-

9 Habermas follows his predecessors', from the school of Frankfurt, critical interpretations very carefully be they from Horkheimer from Adorno. We can consider that the Habermas' critical interpretations are post-marxist having the intention to reconstruct materialism. What Habermas intends to demonstrate is that Marx can be included in the continuity of a critical tradition that has its origin in Kant's critical philosophy. In terms of his theory of ideology developed in the work Knowledge and interest, it is presented in critical terms following the model of psychoanalysis. Criticism is a process of understanding that progresses by means of deviations across a process of scientific explanation. This deviation comprises of what was repressed as the system of repression itself and explains the distorted contents and the system of distortion. The system of the distortion of communication itself must be dismantled and not only the communicative contents. For this reason, Habermas criticises the hermeneutics that dedicates itself to the interpretation and comprehension of the contents, but does not go until the systemic structure of the act of communication. Cf. Ricoeur's lesson on Habermas (2). IU, p. 265-274. 
tion of dissimulation. It is from the positive function of ideology that the function of legitimacy of power is developed. In fact, as the original events are more and more separated, the tendency is for the mechanisation and domestication of memories. Ideology loses its mobilising force, and has the propensity to become a justification of power and of authority, a fact that allows a specific community to express itself at a global level as an indissoluble individual. It is the case, for example, of the old stereotyped commemorations in dictatorial countries in that the automated rituals have as an objective the cult of authority and, simultaneously, the international statement under the sign of cohesion. In this aspect, ideology becomes, as an effect, imprisoning, in that its dogmatic character implies an artificial and authoritarian reading of the existence of a people and of its place in history. The authoritarian power has the tendency to maximise its domain and its historical-cultural importance in world history. Ideology, in this aspect - and using the Althusser's expression -, is an interpolation to the subject on behalf of an only and absolute subject: the State.

If ideology, essentially, points towards the reinforcement and presentation of the present social reality, imagining, above all, the past founder, utopia - as we will see - projects, on the contrary, the imagination beyond what's real, keeping in mind the re-figuration or transfiguration of the human world in the future.

\section{II.}

The concept of utopia was, throughout the $20^{\text {th }}$ Century, a fundamental concept in the political and ideological battles. On the one hand, the liberals, filled with a desire to maintain their social status present and dreadful with relation to the loss of political and economical power; on the other hand, the socialists and communists, projecting themselves into the future, intended to transform social reality by invoking an abstract and imaginary future. Finally, the ultra-conservatives stuck to the past and 
to tradition, confidently irreversible, intended to perpetuate the vestiges of an ideology that is anachronistic in every way.

The classic utopias aspire to a better and safer life, they present themselves as a dream for something better, without any means nor methods for efficient execution. However, the utopian fictions are interesting, even as dreams that are on the borderline of reality because of being situated «between the viable and the impossible» (RICOEUR, 1989, p. 319); have the privilege of giving form to a new reality.

Effectively, in spite of the critical and projective dimension of utopia and of its importance in the contemporary world, it is true that the utopian thought crosses a crisis that is not particularly estranged to what were its pathologies, particularly in the most recent history of the western world.

In spite of everything, utopia in the actual world can quite likely be an investigation on the new values and the new types of relationships among human beings; it can and it should be the result of an interpretation of the historical, social, political and educational reality having as a purpose the search for new horizons of meaning; it cannot be, as it was it in the most recent past, a dogmatic vision of a world pretentiously absolute and closed within itself, a fact that drives it to social forms as well as sinister and totalitarian politics. At any rate, it seems that utopia, considered in its positive sense, is a vital need for human beings and, without it, society cannot project itself into the future. Without a doubt that there is some legitimacy in the refusal of the utopian forms that can, somehow, trap human beings, above all in respect to the fundamental rights; but it is also legitimate to think in new forms of human accomplishment in the society and, particularly, to maintain society and history open to other forms of debate, the other narratives, although, at the moment, aren't known; even worse than an accomplished utopia, than an ideological utopia, is the absence of utopia. At the beginning of the third millennium, more than thinking about new forms of society, it is important to think about new forms of social relationships and in appropriate political strategies that have in mind the decrease of the asymmetries and of all the forms of social exclusion. 
In the educational domain, that utopian dimension or utopistic, as some authors prefer, links to the dream of a school for all, deeply democratic, emancipatory, that integrates and shares the differences and that everybody is guaranteed the right to success. That legitimate dimension, deeply rooted in present events, is the investment in an education towards tolerance, towards peace, against war and against all forms of violence. Education towards tolerance is absolutely necessary to avoid violence.

In fact, from the social experiences lived throughout history in which all that is wrong was and is present - above all in the catastrophic experiences of war -, it should be thought of as a possibility to avoid or reduce in the future. The proposal of an alternative society, from the radical questioning of the existent, answers to an exercise of the imagination to think of another way of being and of existing. To maintain hope alive is, in our opinion, the liberating function of utopia and it is also from school that the hope is reborn.

While the ideology preserves and conserves reality, utopia questions it and reveals the critical capacity of social groups related to all the aspects of social life. It is the expression of non-conformism and of the desire for transformation that characterises the human being in its communicative relationships. It is, Ricoeur affirms, «the dream for another way of family existence, for another way of appropriation of the things and of consumption of goods, for another way to organise political life, for another way of living the religious life» (1986, p. 427), for another way of educating and forming. For that reason, the different utopias produced in history reveal distinct projects in relation to the way of living in society, keeping, however, always in mind social harmony and human happiness.

Utopia, just like ideology, can be inscribed in the symbolic order of the representations; but, in contrast to ideology, utopia configures one for beyond the space and the socio-historical time. It represents a displacement of the action for a promising future that doesn't have its place in any specific space and time. The function of utopia is of projec- 
ting the imagination to an absent place, to the borderline of any reality. It is, as Ricoeur says, "un nulle part " (1986, p. 427). The displacement of the action through representation becomes more manifested in the collective plane; at this level, the representations are, mainly, systems of legitimacy and of justification, be that of the established order or of an order susceptive of substituting the existent order.

The positive function of integration of ideology can correspond to the utopian function for the proposal of an alternative society, imagining new forms of life, of government and of economic production. Before the offer of legitimacy of a social order, that the ideology proposes, utopia exposes the authoritarian pretences of all the existent social systems. In this point of view, utopia has the function of subverting the several forms of political power providing imaginary alternatives about power and about social organization. It is, therefore, always a criticism to the existent power.

What definitively is in game in the whole of ideology is the legitimacy of a certain system of authority; what is in game in the whole of utopia is to imagine a different way to use power (RICOEUR, 1989, p. 221).

Utopia, just like ideology, is confronted with its pathology, in that it can be a crazy, imprudent dream and, at times, bloodthirsty.

In the same way that Ricoeur pointed out a political paradox, he also establishes a paradox of convictions: from the most utopian of convictions, the deadliest of ideologies can be born. Therefore, it is not possible to separate the problem of ideology from the problem of utopia. In fact, if it is from utopia that one can criticise ideology, the positive function of ideology can preserve us from the possible madness of utopia.

In its negative dimension, utopia, for its dogmatic character, can lead to repressive politics, as, for example, to dictatorships and to subtle forms of authoritarianism.

The ideological utopia may well be the expression of the negative and totalitarian slope, so much of utopia as of ideology, while structural phenomenons of the symbolic and cultural imagination. That of which 
exists positively and genuinely in ideology and in utopia is lost from the moment in which both concepts are joined together. Ideology can be distorted and mystified, but it can also be a symbolic and integrative vision of the human action; alternatively, utopia can be the expression of a social pathology, but, besides that, it can be liberating at the level of social imaginary. From the moment in that an ideology intends to be the real expression of a utopia, we stand before an ideological utopia, that is to say, before a totalitarian distortion of the real that "announces future tyrannies" (RICOEUR, 1986, p. 429). It is what Ricoeur demonstrates in the following text:

A type of mad logic of everything or nothing substitutes the logic of the action, which always knows whenever the desirable and the easily accomplished are not coincident and that the action produces evident contradictions, for example, for our modern societies, between the demand for justice and the one for equality. The logic of utopia becomes, then, in a logic of everything or nothing that, to some leads to separation through writing, to others to the closing in a nostalgia of the lost paradise, and to others still to kill indiscriminately (RICOEUR, 1986, p. 430).

Effectively, the known utopian narratives, from the Republic of Plato, The best of republics by Thomas More, The city of the Sun by Campanella, to the New industrial and societarian world by Fourier and The best of worlds by Huxley, build a society from an intellectual model. The idea of the construction of a society a priori can explain the dogmatisms of the utopias. From an absolute truth there is an intention to apply it to the citizens eliminating, in final analysis, the individual rights in favour of an idea that is allegedly collective. Private life is invaded and controlled, the dissidents are pursued and eliminated and all critical spirit is annihilated. The sinister idea prevails, in this way, reality.

In fact, nobody can make politics if one doesn't have a proposal of an ideal to the level of social and economical relationships, under the 
possibility of falling into a vulgar pragmatism or of limiting oneself to administer what exists without any concern of transforming it. There is no existence, therefore, of a political thought without innovative projects related to the existent reality. It is this that can distinguish a true man of State that wants to exercise power with the purpose of transforming social reality, from a simple politician. The man of State always "wants the best of all worlds", while the simple politician intends to, just, reach power for the sake of power. In this perspective, utopia can be inserted into the context of political ideals based on a reality that urges to transform and not in a reality based a priori on a model to the borderline of social reality. In this sense, utopia, considered as a human ideal, has a character that allows transformation, it "represents the largest revindication of an accomplishment" (RICOEUR, 1986, p. 430) since it is a criticism to the existent social structures. Thus, utopia is what it should be, in opposition to what it is; "it wants to be an eschatology that has been accomplished".

In this aspect, Ricoeur questions the function of the Christian faith in the dialectic between ideology and utopia. He refers to the "fundamental utopia", an expression inspired by the patristic theology, which points to the unit of the human kind and to the personalisation of social relationships. However, can't this "fundamental utopia", itself, be an ideology?

What, speaking of which, can be said is that faith possesses both dimensions in that, on the one hand, it is the attachment to tradition and dogma and, on the other hand, it is an acceptance of an ethics of conviction that can, in fact, inspire new perspectives of power and of society. ${ }^{10}$ In the presence of danger of the pathology of the utopias that, ultimately, intend the historical accomplishment of its ideals, eschatology has a critical function that impedes the confinement of utopia unto itself. The eschatological Christian dogmas allow the apparent absurdity of history

10 Through Max Weber, Ricoeur establishes the distinction between a moral of conviction, which is a moral of absolute desirability, and one of responsibility, which is a moral of the relatively possible and also of the limited use of violence. Cf. El problema del fundamento de la moral. Amor e justicia, p. 93. 
to overcome, in that, thanks to them, the dangers from history are not a source of fear or of distrust. The Christian, living in the ambiguity of the profane history, inscribes it in a sacred history that, for him, has meaning, although hidden in mystery. It is the faith in redemption and in salvation that dominates the whole vision that the Christian has of history. ${ }^{11}$ The Christian hope, substantiated in the ethics of the Sermon of the Mountain, provides a global horizon of meaning that inspires the utopias and gives strength to the action; however, the Christian hope always remains in the symbolic order and one beyond history, this does not mean that it doesn't have a role of reference for social existence in present history. ${ }^{12}$

In the presence of a moral responsibility, «a moral of force, of regulated violence, of the calculated guilt», ${ }^{13}$ that can drive to a political realism or to a Machiavellism, a moral of conviction is proposed that can make a constant pressure on the morals of responsibility, conferring the political and economical action a human face as an objective, in other words, "to want humanity as a whole (...) and to want a person as a singularity" (RICOEUR, 1991, p. 252). It is not, adds Ricoeur, of the immediate accomplishment of this moral - the one of conviction - but of "expressing it indirectly by the group of pressures that it can exercise on the morals of responsibility" (1991, p. 252).

Utopia, not withstanding being linked to the morals of conviction, may well be a form of pressure over the most perverse tendencies of political action; it can, therefore, be a vigilant moral and, even, an inopportune moral.

When referring to Th. Munzer, Ricoeur affirms that utopia represents "the largest revindication of an accomplishment, here and now, of

11 Ricoeur, P. El cristianismo y el sentido de la historia. Hv, p. 73-87.

12 Ricoeur, P. El cristianismo y el sentido de la historia. Hv, p. 73-87. We must consider the dogmatic and precisely acritical role that, in fact, the cristian faith had, including the eschatologicals, throughout history.

13 Ricoeur, P. (1976). L'hermenéutique de la sécularization. Ideologie et utopie. Archivio di filosofia, 2. p. 49-68. 
all the dreams that the imagination accumulated, through Judaism and Christianity, in the representations of the end of history. Utopia wants to be an accomplished eschatology" (1986, p. 429) in the present.

In any case, the intention of utopia is to change reality; it is to produce a new reality that is beyond the present time, although based in the present and in the past. It is in this aspect that the productive function of imagination has pertinence. We see the way Ricoeur presents us with the function of imagination in ideology and in utopia: On the one hand, imagination can work to preserve an order. In this way, the function of imagination consists of placing in scene an identification process that reflects that order. Here, imagination has the appearance of a picture or painting. But, on the other hand, it can have a destructive function and it can also promote progress. In this way, its image is of production; it is to imagine something different, a nulle part. In each one of its three roles, ideology represents the first imagination type because it has a function of preservation, of conservation. In contrast, utopia represents the second imagination type; it is always a glance from a place that doesn't exist.

From what was displayed, it makes sense to establish the relationship between the role of imagination in utopia and in metaphor. In fact, the productive imagination drives leads the thought to think beyond the present. In the same way, the symbolic function of the metaphor doesn't intend to illustrate something already constructed, but to introduce a new dynamic in the activity of thought, in that the metaphor is "change" (RICOEUR, 1980, p. 30). The metaphor is, therefore, a heuristic instrument that, through the conjunction of opposed semantic plans, inspects the plans and the possible situations that allow a new meaning for the world beyond the literal meaning. In this perspective, utopia, while a metaphoric reality, reveals a possible truth in contrast to the ideological, literal truth; utopia, like metaphor, is an innovation of meaning and a violation of the existent meaning. Metaphor takes into consideration, not only the structure of language, but also the structures that we, usually, call reality and truth. It is, without a doubt, the creative character of metaphor that 
is important to enhance here: in that it is a re-description of reality, it is the invention of a new reality.

Actually, what characterizes the human being is the capacity to act on the real, for creating new realities and transforming the existent ones. Utopia, considered as metaphoric discourse has the function to re-describe and to invent a new social and political reality and it may very well be a new discourse on power. At the social level, utopia has, therefore, this metaphoric quality of exploration of possibility, that is to say, of making new horizons of discourse emerge and of revealing the real as an act. If utopia is something that is open to another possible discourse, perhaps even to a reinvention of social emancipation, it consists, then, in the metaphoric transformation of the existent social discourse, in other words, of the ideological discourse. In this perspective, the metaphoric discourse has an ontological function and the utopian discourse is, it can be said, potentially ontological.

The utopian quality of imagination takes us from the constituted reality to the constituent reality; in fact, the basis of the idea regarding utopia is the one from "nulle parte", in other words, it is from an externalising space, from the absence of a place that casts a glance to the existent reality what it means that utopia allows us critical apprehension of the existent reality and it offers us new possibilities that transcend the present reality: "to imagine a non-existent place, is to maintain the field of possibility open” (RICOEUR, 1986, p. 430). In this perspective, utopia is an interesting possibility to rethink the reality of the existent social institutions; it is, adds Ricoeur, "this development of new possible perspectives that defines the most important function of utopia. (...) It represents the fantasy of an externalising possible society in "no particular place" - from history - that acts as one of the most formidable repudiations that exists ".

In fact, it is this radical level of utopia, while a constitution of another symbolic social action that is opposed to the concept of ideology considered to its level of social integration. Besides that, if the ideology 
is a form of legitimacy of power and of authority, utopia, in its own way, intends to be a reflection about power, about its credibility and that of the institutions submitted to power. The clarity of Ricoeur's words avoids that, purposefully, comments be made:

What definitively is in game in utopia is not so much consumption, the family or the religion, but the use of power in all these institutions. Won't it be because of the fact that a breach of credibility exists in all these systems of legitimacy of the authority that a place for utopia also exists? (RICOUER, 1989, p. 59).

From all the analysis that has been carried out regarding ideology and utopia, we can, now, question its place in the plan of collective life.

It is not possible - it seems to us - to think that the existence of collectiveness that is on the margin of conflict, never resolved, between ideology and utopia and to the margin of the polarity that exists between both. Ideology confers the feeling of belonging to a culture, to a tradition it is a type of permanent remembrance of the origins and of the inaugural events. From this we witness its conservative character. In its own way, utopia, in its function to criticise the present reality and of the projection to another place, not only does it populate the collective imaginary, as it constitutes a radical critique to the conservative reality and many times dogmatic of ideology.

In fact, ideology and utopia are linked and they are an integral part of social and cultural imagination (RICOEUR, 1989, p. 45). On the one hand, ideology can represent the attachment of a certain community to tradition and to its desire for cohesion and for a "narrative identity"; ${ }^{14}$ it is always through ideology that a people or social group represents its own

14 What Ricoeur intends by narrative identity is the consciousness of belonging to a specific community culture and tradition. Through ideology, the social group reaffirms itself in its own identity and has a tendency to preserve and conserve. Cf. TA, pp. 427 and 431. 
existence, although, many times, such representation can be mystified; on the other hand, utopia represents the critical spirit relative to a present social order and, inclusively, to the need for projection beyond the present time, in another order that is not the established one. To consider the reality in its dynamism and the possibility of its transformation through the human action implies a projection beyond it and the maintenance of a critical distance in relation to it. Utopia "is always a separation between the imaginary and the real, a separation that constitutes a threat to the stability and the permanence of that reality" (RICOEUR, 1986, p. 428). It is, therefore, in the alternative perspective and of change relative to the present reality that utopia should be analyzed.

To think of a possible world, more human and with more solidarity, implies that the necessary tension between what is and what should be ought to always be present. From this, the conflict between ideology and utopia is always an open conflict between tradition and memory as well as expectation, just as between the space of experience and the horizon of expectation.

The problems of ideology and utopia should fit into the wider context of Ricoeur's thought. We are convinced that these problems are inscribed in the plan of an anthropology of freedom, of ethics and of ontology. Actually, human freedom is only really affirmed in the connection, although conflictive, between cultural legacy and creative innovation, in the context of the permanent desire to just be. Utopia, necessary in contemporary times, is the duty and the capacity that all human beings possess to transcend the present moment, to improve himself and to contribute, constructively, to a future that is freer and that shows more solidarity. The utopia that is necessary today doesn't have to do with the historical utopias that intended to create a paradise on earth; it links more to man's need for an internal conciliation as well as conciliation with others, with the construction of a system of freedom and of respect for the human person. As Bernard Lwn affirmed, the winner of the Nobel Peace prize in 1985, "only those that see the invisible can achieve the impossible ". What matters today is that the spirit of utopia doesn't 
perish, that imagination triumphs since it is the engine behind the whole process of invention.

Utopia can render a service today, in a time where society has many means and few objectives; I really think of the utopia that debilitates the State in the great liberal authors, in the anarchists, in Lenin of the State and the Revolution; as a matter of fact by means of the utopia at the end of the State - at least of the repressive State just as we know it today -, we dream about the reconciliation of politics with friendship; yes, we dream about a State that is just the administrator of things and the people's educator of freedom. This utopia is vital for politics' own destiny; it is the one that gives it its purpose, its tension, its hope"..$^{15}$

Without forgetting cultural traditions and the finitude of existence, it is, with effect, of recovering the capacity of projection and interrogation that the human being has, of giving body to man's multiple dissatisfactions with the purpose of solving humanity's great problems. Utopia should, again, find the creative capacity to imagine new forms of urban planning keeping in mind the social aspects and of quality of life implied in it; it should take into consideration a post-industrial society, ecologically viable and human; it should think of new labour relations, develop the tasks of the education and of formation for the citizens taking into account the equality of social opportunities.

The citizens are part of an ethical order and of a political order within which conflicts emerge naturally. The democratic societies are the privileged public spaces where such conflicts can take place, taking into consideration that it is in them that the plurality of differences among the citizens can be manifested. Though, besides the individual responsibility that implies a belonging to a democratic society, the collective responsibility constitutes the moral basis for the functioning of institutions. Ricoeur considers that the problem of collective responsibility is one of the political educator's tasks.

15 Ricouer, P. Perspectivas teológicas. HV, p. 110-111. 
Starting off with a reflection on the instruments of collective responsibility, the institutions and the values, Ricoeur affirms that the task and the political educator's responsibility begins at the level of the instruments, since the contemporary society is responsible for the growth of those same instruments, that presupposes, in our perspective, a rational planning and a collective choice relative to the future. The world of the future will, constantly, be the theatre of collective decisions, be it in the economic, in the social or in the political aspect. With clarity, Ricoeur highlights:

If the current development of our societies is the result of a collective creation, this will also demand a collective responsibility. We have to therefore create the instruments of this collective responsibility. It is what I call "economic democracy" (RICOUER, 1991, p. 250-251).

Going back to the subject of utopia, from the current conditions of our collective existence that should, in our opinion, take into account the subjects that are placed in humanity today, such as globalisation and the preservation of the foundations of local cultures with the objective to decrease the tension between the global and the place. How can we conciliate, for example, the condition of citizen of the world with the preservation of cultural roots, the traditional and the modern, the world economy and the private needs?

Taking into account that the utopian thought should not be dogmatic and absolute, the thoughts or ideas about the future should come from the contingency and the relativity of the present and the answers can only be plural and relative, since the construction of the future is always an open road, that it should keep in mind the principles of pluralism, of the statement and preservation of differences and of freedom. Utopia should, therefore, aspire to imagine the future from the subjects that the actual world puts forward, integrating, as much as possible, the positive aspects of the past, above all those that constitute the identity of each 
one of the cultures. It is for this reason that the phenomenon of utopia, while a fiction that has the power to re-do reality, only has pertinence through its intertwinement with history; on the other hand, history, while interpretation, while open to the future, becomes meaningful when connected to utopia. What is truly important, in final analysis, is that the future can be materialised in symbolic images that have a cultural significance of their own and that don't produce a radical rupture with the primordial aspects of the cultural identity, that is to say, a rupture with the "ethical-mythical nucleus" ${ }^{16}$ creation of a culture. It is this aspect that can be taken into account in the phenomenon that is globalisation, above all if this phenomenon intends to affirm itself as a type of cultural homogenisation, as a global ethnocentrism or, as Boaventura de Sousa Santos affirms, as a global location. ${ }^{17}$ The reconstruction of utopia should be, we think, a redefinition of the political and social models of the future that keep in mind the own redefinition of the notion of cultural identity. It seems to us that the notion of belonging to a territory, to a history, to a religion or to a race, may not have pertinence in the future. The citizens are, more and more, citizens of a world without borders, in which the signs of identity tend to dissolve.

In fact, the proliferation of the media and the diffusion of information takes the individuals and the people of a nation to be in permanent relationship and to live in a present without borders, which implies the appearance of a new culture of communication that, in every moment, is aware of world events to the margin of the tradition space-time references. The virtuality of social and economical relationships become an unquestionable phenomenon that cannot, however, pervert the true socio-cultural relationship, fragment the individual cultures and impede interpersonal communication, a fundamental basis of social ethics.

16 Ricoeur, P. Civilización universal y culturas nacionales. HV, p. 258.

17 see (2000) Critica da razão indolente. Contra o desperdício da experiência. Porto: Edições Afrontamento, especially under the chapter Da ciência moderna ao novo senso comum, p. 53-110. 
Consequently, utopia should be "a method of investigation that allows one to think about the future critically, more than a regulated programming of humanity's destiny" (AINSA, 1997, p. 183). Also, because of this, utopia can be deceiving if it is not articulated with the possibilities that are presented to man in each historical period.

Taking into account that humanity's future is threatened by the evolution of science and of technique, through the subordination of the first to the second, through the subordination of both the great economical monopolies and through the increasing investment in warlike industry, the man of today is responsible, not only for his actions in the current world, but also for the way that he perceives the future. Responsibility for the future is, nowadays, an ethical imperative. It is the function and duty of all humanity to safeguard the future of the new generations and, in this way, utopia, more than a principle of hope, is a principle of responsibility that has in mind the preservation of the future through responsible actions in the present. According to Hans Jonas's perspective, we are responsible for humanity's remote future, beyond the limited horizon of the predictable consequences of our actions. We are, ultimately, responsible for the perpetuation of humanity's history. ${ }^{18}$

Along the same lines, Ricoeur manifests his concern emphasising the ethical dimension of interpersonal relationships to the future of humanity's history. He writes:

The imperative is relatively new to the simple idea of respect for a person, in that it surpasses an ethics of proximity marked by the concern of reciprocity. Responsibility, in the technological era, is emphasised in such a way in relation to the future like our powers in space and in time, and in the depth of life. ${ }^{19}$

18 Jonas, Hans (1990). Le Principe responsabilité. Paris: Éditions du CERF. Cited by Ricoeur, «Postface» Temps de la responsabilité, in L1, p. 282.

19 Jonas, Hans (1990). Le Principe responsabilité. Paris: Éditions du CERF. Cited by Ricoeur, «Postface» Temps de la responsabilité, in L1, p. 283. 


\section{III.}

The neo-liberal ideological discourse, conservative that, currently, intends to give form to the educational phenomenon points towards the conflict between the private and the public educational institutions. The first, capable of responding to the needs of the market through an education towards excellence; the second, essentially massifying, is, according to them, sustained in mediocrity. Now, this conservative ideological discourse represents the attempt to recover an elitist conception as well as one of meritocracy of the education and the abandonment of the democratic discourse, sustained in the universal right to education, in the equality of opportunities and in the introduction of compensatory measures. It is a conflict of interests that reaches education and that seeks a lack of responsibility with regard to the State and as well as the transferral of educational responsibility to civil society.

The traditional educational model seems to be saturated, above all in respect to its traditional scholars. Still, the nuclear model of the traditional school remains in structural terms through its natural merit, in that it, still, permits the teaching of all those as if it were only one. It is, therefore, an educational paradigm that is adjusted to massification. However, this model cannot subsist because massification is generating its own destruction. On the one hand, because it doesn't respond to today's existent differences; and on the other hand, because the models of authority and of discipline that are proposed are put into account in function of a growing heterogeneity. Nevertheless, it is not through the decadence of the existent educational paradigm that it should propose its opposite, that is to say, the return to an elitist and non-inclusive educational model.

The challenges that are placed in education are linked with the need to adjust to a society that is, more and more, a society of knowledge and of information and to the new emergent cultural realities, resulting from the phenomenon of globalization and of the intersection between different 
cultures. On the other hand, if learning surpasses the cognitive domain and if the challenge that is placed on all the citizens is that of learning throughout life, the school will have to capture other scholars, other publics already schooled in order to satisfy that objective. The challenges with regard to education are located, therefore, between ideology and utopia, between the literal and the metaphoric. To assume, against the elitist discourses, the responsibility of education and of the formation of citizens' of all age levels is, without a doubt, a perspective that is possible, but that is still inscribed in the context of utopia.

To know the ideologies that, at all times, configure the educational politics is a part of the deontology of all those that are a part of the educational community; to produce counter-ideologies and utopias in the sense of contributing so that this century doesn't dissolve the inalienable right that everybody has to receive education, to quality education and formation, to a new education supported by the dream and that refuses discouragement, is an ethical demand. The school as a space and place for emancipation, for debating ideas, for communication, for formation and for the affirmation of identities and differences is the horizon of hope.

\section{Bibliographical references}

AINSA, F. (1997). La reconstruction de la utopie. Paris: Arcanteres.

CRAGNOLINI, M. B. (1992). El concepto de razón práctica de Ricoeur: entre el proyecto de libertad y las tradiciones. Escritos de Filosofia, 21-22. Buenos Aires.

JONAS, H. (1997). Le principe responsabilité. Paris: Éditions du CERF.

MARTINEZ, T. C. Remedios, A. C. (Eds) (1991). Paul Ricoeur: los caminos de la interpretación. Barcelona: Anthropos.

RICOEUR, P. ( 1991). Lectures 1. Autour du politique. Paris : Éditions du Seuil. (L1) 
, P. (1976). L'hermenéutique de la sécularization. Foi, idéologie et utopie. Archivio di Filosofia, 2. 49-68.

, P. (1980). La metáfora viva. Madrid: Ediciones Europa. (MV)

, P. (1984). Temps et récit 2. La configuration dans le récit de fiction. Paris: Éditions du Seuil.

, P. (1985). Temps et récit 3 Le temps raconté. Paris: Éditions du Seuil.

, P. (1986). Du texte à l'action. Essais d'herméneutique II. Paris : Éditions du Seuil. (TA)

, P. (1990). Historia y verdad. Madrid: Ediciones Encuentro. $(H V)$

, P. (1992). Lectures 2. La contrée des philosophes. Paris : Éditions du Seuil. (L2)

, P. (1993). Amor y justícia. Madrid: Caparrós Editores. (AJ)

, P. (1994). Lectures 3. Aux frontières de la philosophie. Paris : Éditions du Seuil. (L3)

, P. (1989) Ideología y utopía. Barcelona: Gedisa. (IU)

RICOEUR, P. (1985) Lectures on Ideology and Utopia, ed., trad. George H. Taylor. New York: Columbia University Press.

SANTOS, B. S. (2000). Crítica da razão indolente. Contra o desperdício da experiência. Porto: Afrontamento.

Data de registro: $01 / 07 / 2015$

Data de aceite: 30/03/2016 